\title{
Incidence of Complications in Patients Treated with Plaster Splints in Emergency Departments in four Hospitals
}

1 Mario Gašić

1 Harolt Placento

1 Zvjezdana Gvozdanović

2 Marijana Neuberg

3 Mario Djuran

1 Kristina Tičić

1 GH Našice

2 University North

3 GH Varaždin

Article received: 13.04 .2017$.

Article accepted: 06.09.2017.

Author for correspondence:

Mario Gašić, Bana Josipa Jelačića 10, 31500 Našice, magasic@unin.hr

DOI: $10.24141 / 2 / 1 / 1 / 7$

Keywords: emergency departments, plaster splint, education, complications

\section{Abstract}

Aim: 1. To determine the frequency of complications in patients treated with plaster splint at emergency departments. 2. To determine the existence of correlation of complications in patients treated with a plaster splint at emergency departments with prior work experience in surgical plaster rooms.

Hypothesis: Frequency of complications in patients treated with plaster splints at emergency departments whose immobilization is performed by nurses with prior work experience in surgical plaster rooms is lower than in patients whose immobilization is performed by nurses educated for the needs of plastering at emergency departments.

Materials and methods: Research - April and May 2015, at Našice General Hospital, University Hospital Centre Osijek, Čakovec County Hospital and Dr. Tomislav Bardek Koprivnica General Hospital. Sample - 153 patients and 34 nurses. Research instruments - two anonymous questionnaires created for the purposes of research. Descriptive and nonparametric statistical data analysis has been applied with $\alpha=0.05$ level of significance.

Results: pressure sores of different intensity are present in $8.9 \%$ of the second group respondents. This complication is not present in the first group. Plaster splints in the first group are adequate in $86.7 \%$ of cases, while they are not adequate in $59 \%$ of the cases in the second group.

Conclusion: The hypothesis has been confirmed. 


\section{Introduction}

Dorsal forearm and shin plaster splints are most commonly used immobilization devices in everyday work (1). Fractures, sprains and contusions of wrist and ankle are the most common injuries that are an indication for treatment using those types of immobilization $(2,3)$. In the Croatian health care system, fresh traumas are usually treated at Emergency Departments (ED) where immobilization is most commonly used. Nurses - plaster makers are an integral part of $E D$. Using our knowledge, we defined the origins of two groups currently working at EDs. One group had experience of working at outpatient clinics as plaster makers, while the others were educated at EDs to meet their needs. Thus, a question arose "Is there a difference between these two groups?"

Aim: 1. To determine the incidence of complications in patients treated with plaster splints at EDs. 2. To establish the existence of a connection between complications in patients treated with plaster splints at EDs and experience of nurses who perform immobilization. Hypothesis: The incidence of complications in patients treated with plaster splints at EDs where immobilization is administered by nurses with prior experience in surgical plaster rooms is lower than in patients whose immobilization is performed by nurses trained in immobilization at EDs.

\section{Methods}

Respondents consisted of a sample of patients treated at hospital emergency departments at Našice General Hospital, University Hospital Centre Osijek, Čakovec County Hospital and Dr. Tomislav Bardek Koprivnica General Hospital. The study included patients who were primarily treated at EDs due to injuries of the musculoskeletal system which were treated with a dorsal forearm or shin plaster splint. The research also included nurses who performed immobilization on patients treated at EDs. The respondents were between 10 and 90 years old and have not been diagnosed with diabetes and had not previous- ly undergone repositioning of bone fragments. The sample comprised of 153 patients and 34 nurses. Respondents were divided into two groups. One group consisted of respondents treated at institutions in whose EDs immobilization is performed by nurses who have experience of working in surgical plaster rooms, while the second group included respondents treated at institutions in whose EDs immobilization is performed by nurses who were trained for working at EDs plaster rooms. Institutions were coded and the first group comprised of institutions 1 and 3 , while the other group consisted of institutions 2 and 4 . The research used stratified random sample. Both groups were uniform in their demographic properties. The research was carried out in April and May 2015. The study used two questionnaires structured to meet the needs of this research. The first questionnaire was used to assess the immobilization and consisted of two parts. The first part was filled out by a respondent-patient (age, sex, exclusion factor, evaluation of immobilization comfort, subjective difficulties, estimation of pain intensity, wearing time) and the second part was filled out by a research associate (questions: types of immobilization, complications during wearing the immobilization device, assessment of immobilization device's technical performance). The second questionnaire was intended for nurses who performed imobilization and it consisted of demographic questions (age and gender), questions about the level of education, experience of working in operating rooms or at EDs, satisfaction with education, whether the education was sufficient and whether they were willing to participate in further education. Questions in both questionnaires were both open-ended and closed-ended.

\section{Ethics}

The approval of the ethics committees of Našice General Hospital, University Hospital Centre Osijek, Čakovec County Hospital and Dr. Tomislav Bardek Koprivnica General Hospital was required for the purpose of conducting the research as well as the approval of the Committee for Ethical and Status Issues of Nurses and Technicians in University Hospital Centre Osijek. Ethics committees from all these institu- 
tions gave their consent to conduct research. Before their inclusion in the study, all respondents were informed about the research purpose. They received a verbal notification and a written notice, as well as an informed consent for participating in the study. All respondents volunteered to participate in the study, which was confirmed by their signatures. The study was conducted in accordance with the ethical principles of the Declaration of Helsinki.

\section{Statistics}

Statistical analysis was performed using the statistical program SPSS 22.0 (SPSS Inc., Chicago, IL, USA). We used the Kolmogorov-Smirnov test for testing normal distribution of numerical variables. The comparison of nominal variables in the case of a large number of samples (more than five in a cell) was performed using the Pearson's chi-squared $\left(\chi^{2}\right)$ test, while we used the Fisher's exact test in the case of a small number of samples. When comparing numerical nominal variables with a normal distribution of numerical variables, the Student's t-test and ANOVA parametric test were used, while in abnormal distribution we used the Mann-Whitney and the KruskalWallis tests. The level of statistical significance for all comparative tests was $p<0.05$.

\section{Results}

In terms of gender, in the first group we had 38.7\% (29) of women and $61.3 \%$ (46) of men, and in the second group $41 \%$ (32) of women and 59\% (46) of men (Pearson's chi-squared, $p=0.766$ ).

The difference in average age between the two groups was not statistically significant; the average age of the respondents from the first group was 30.80 years and the average age of the respondents from the second group was 35.86 years (Mann-Whitney test, $p=0.380$ ).

\section{Immobilization Assessment - respondents treated with immobilization}

To the claim "Immobilization was comfortable" respondents in the first group expressed their agreement in $98.7 \%$ of cases. In the second group, the same statement was made by $38.5 \%$ respondents (Pearson's chi-squared, $p=0.000$ ).

To the claim "While I was wearing the immobilization device, I felt..." respondents from the first group, $60 \%$ of them, did not list any difficulties, while in the second group the same was done by $34.6 \%$ of respondents (Pearson's chi-squared, $p=0.000$ ).

Respondents from both groups assessed their pain intensity with an average score of 2 (Mann-Whitney test, $p=0.354$ ).

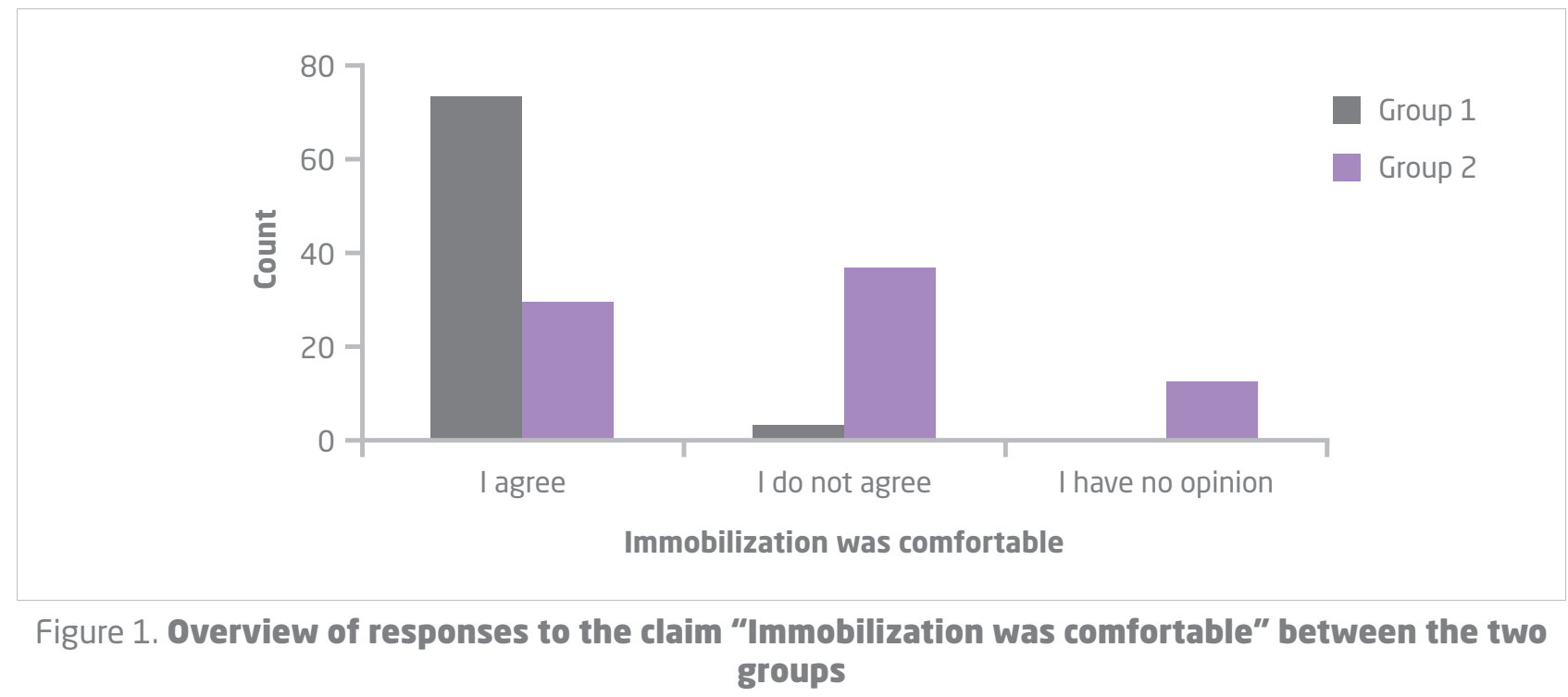




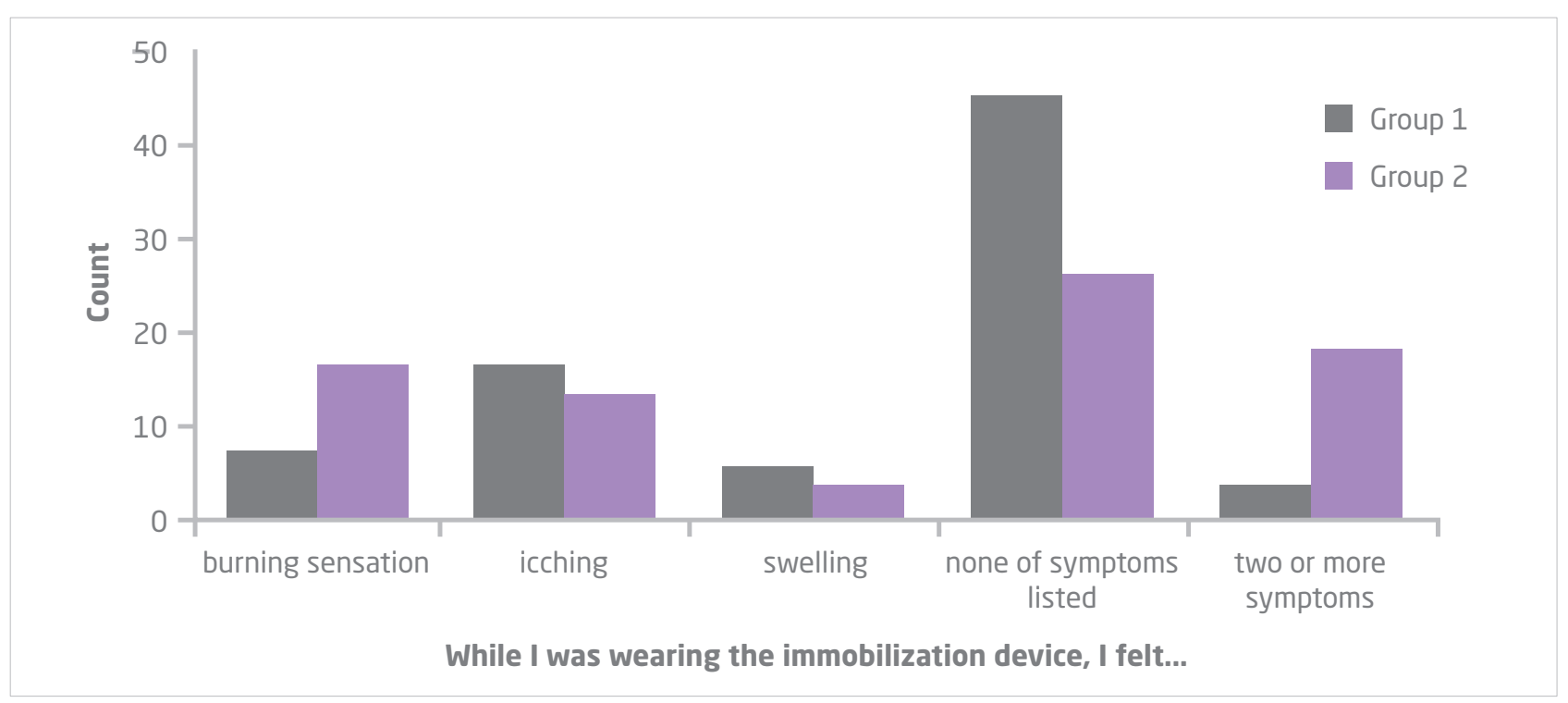

Figure 2. Overview of responses to the claim "While I was wearing the immobilization device, I felt..." between the two groups

Respondents from the first group had on average spent 6.89 days wearing the immobilization device, while respondents from the other group had it for 7.4 days (Mann-Whitney test, $\mathrm{p}=0.001$ ).

\section{Immobilization Assessment 2 - research associate}

The first group consisted of a total of 75 respondents (28\% forearm immobilization and $72 \%$ shin immobilization) who evaluated immobilization devices, while the other group consisted of 77 respondents (56.4\% forearm immobilization and $43.6 \%$ shin immobilization) (Pearson's chi-squared, $p=0.000$ ). No complications were experienced by $78.7 \%$ of respondents from the first group, while in the second group that score was $71.8 \%$. In the second group, $8.9 \%$ of patients experienced pressure ulcers of varying degrees (Fisher's exact test, $\mathrm{p}=0.121$ ).

In the evaluation of technical features of immobilization devices, the first group had $86.7 \%$ of immobilization devices that were adequate, while in the second group only $41 \%$ of immobilization devices were considered adequate (Pearson's chi-squared, $\mathrm{p}=0.000$ ).

\section{Questionnaire for nurses}

The first group consisted only of male nurses who performed the immobilization (12 male nurses), while the second group consisted of nurses of both sexes; male nurses $45.5 \%$ (10) and female nurses 54.5\% (12) (Fisher's exact test, $p=0.002$ ). Male nurses from the first group were younger - 31.5 +/- 9.276 years old on average, compared to the second group where nurses were $44+/-10.508$ years old (MannWhitney test, $p=0.626$ ).

In the first group, $75 \%$ of male nurses had completed a secondary education, and $25 \%$ had a higher degree, while in the second group 59.1\% respondents had completed a secondary education, and $36.4 \%$ had a higher degree and $4.5 \%$ of nurses had a university degree (Fisher's exact test, $\mathrm{p}=0.808$ ).

Male nurses from the first group all stated that their knowledge on plaster splints was a result of their work in surgical plaster rooms, while $81.8 \%$ nurses from the second group responded that their knowledge on plaster splints was a result of education required for working at EDs (Fisher's exact test, $p=0.000)$.

In the first group, $58.3 \%$ of male nurses rated their satisfaction with education as good, while $41.7 \%$ of them rated their satisfaction as very good. Respondents from the second group, $27.2 \%$ of them, rated their satisfaction with education as very bad and bad and $13.6 \%$ of them rated their satisfaction as neither good nor bad. Good grade was given by $59.1 \%$ of nurses in the second group (Fisher's exact test, $p=0.005$ ). 


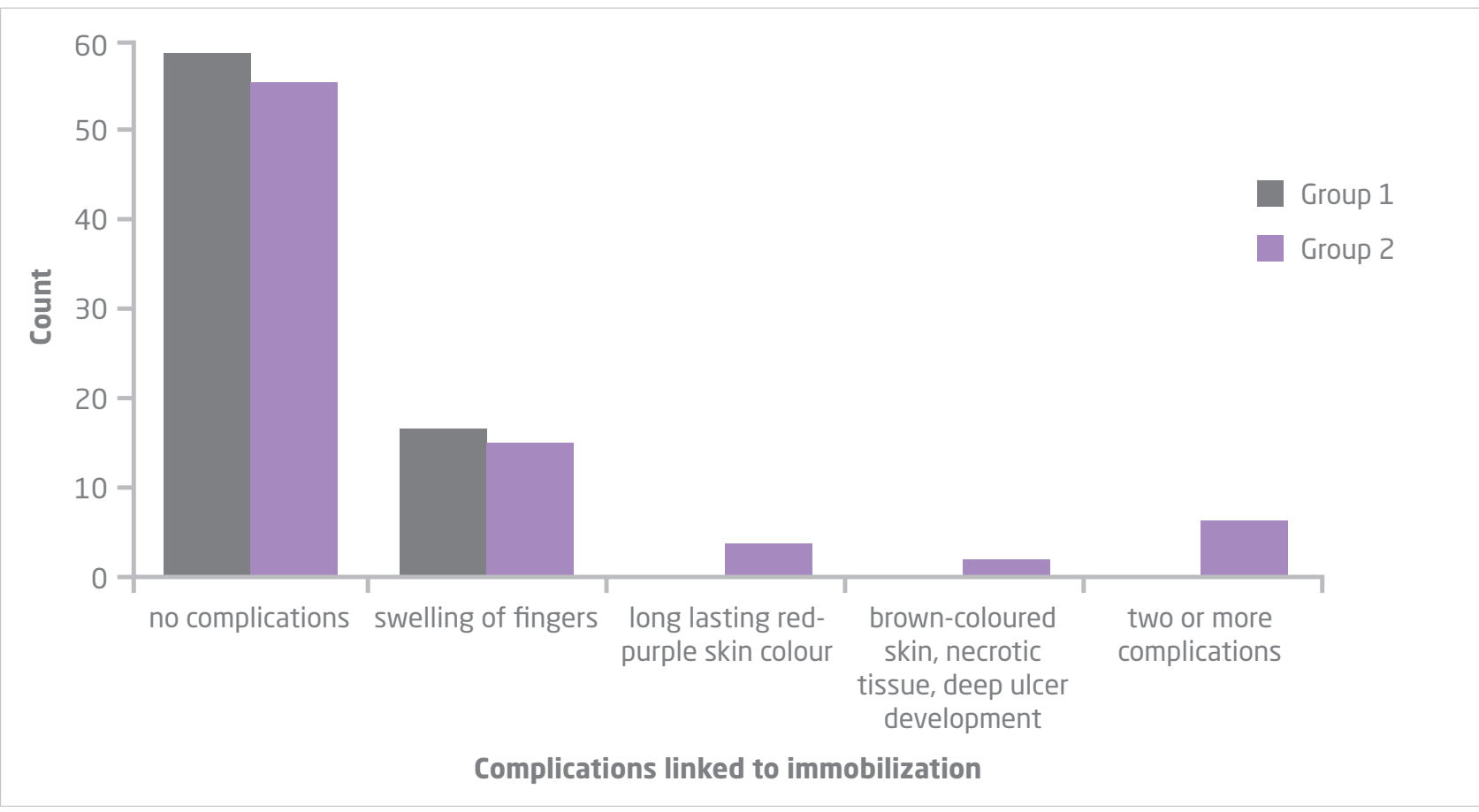

Figure 3. Overview of incidence of complications linked to immobilization between the two groups

When asked "Do you think that education on administering plaster splints which you have received is sufficient?" 91.7\% respondents from the first group said "yes", while only $36.4 \%$ of respondents from the second group answered in the same way (Pearson's chi-squared, $p=0.002$ ).

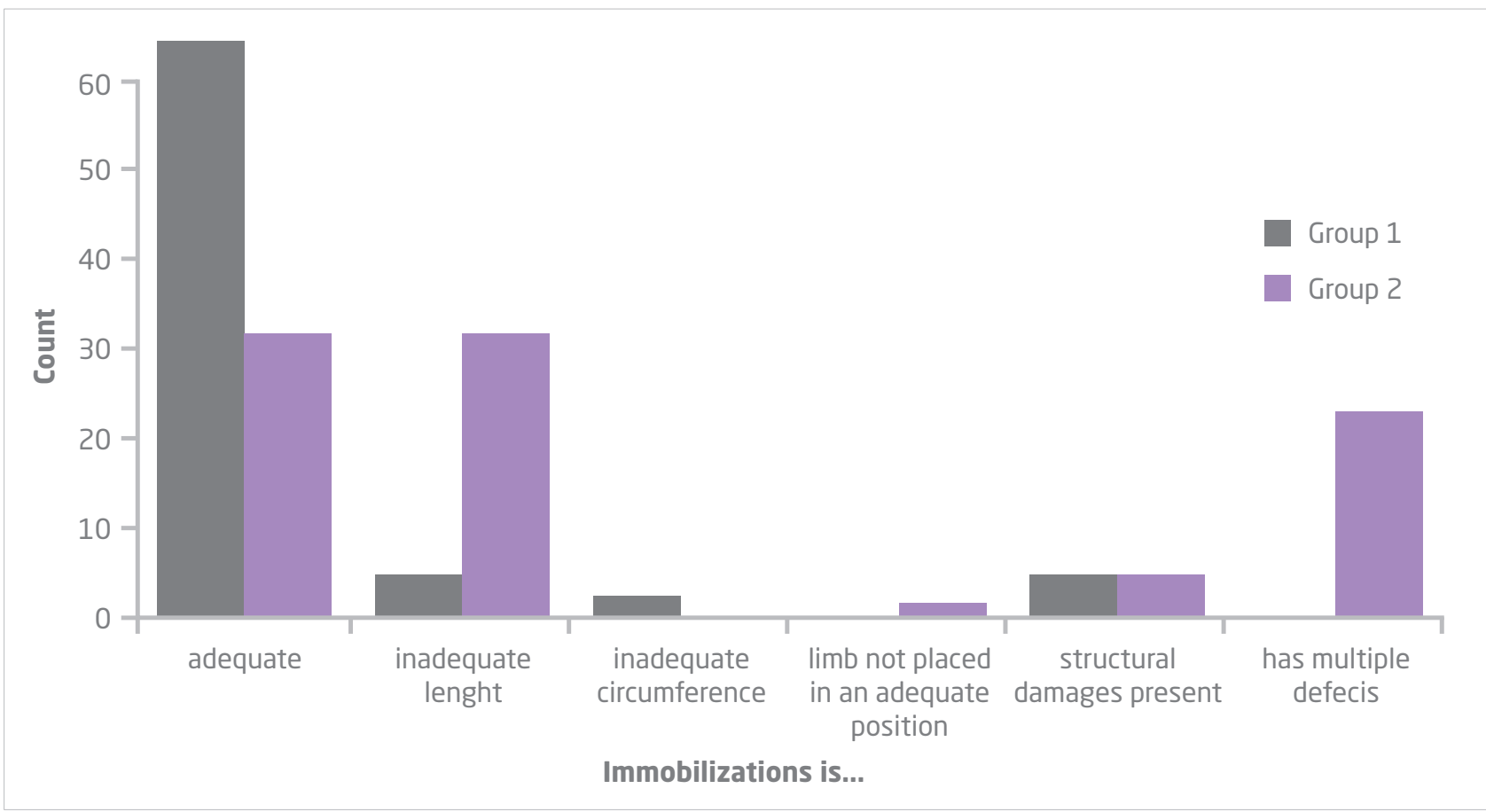

Figure 4. Overview of responses between the two groups regarding technical characteristics of 


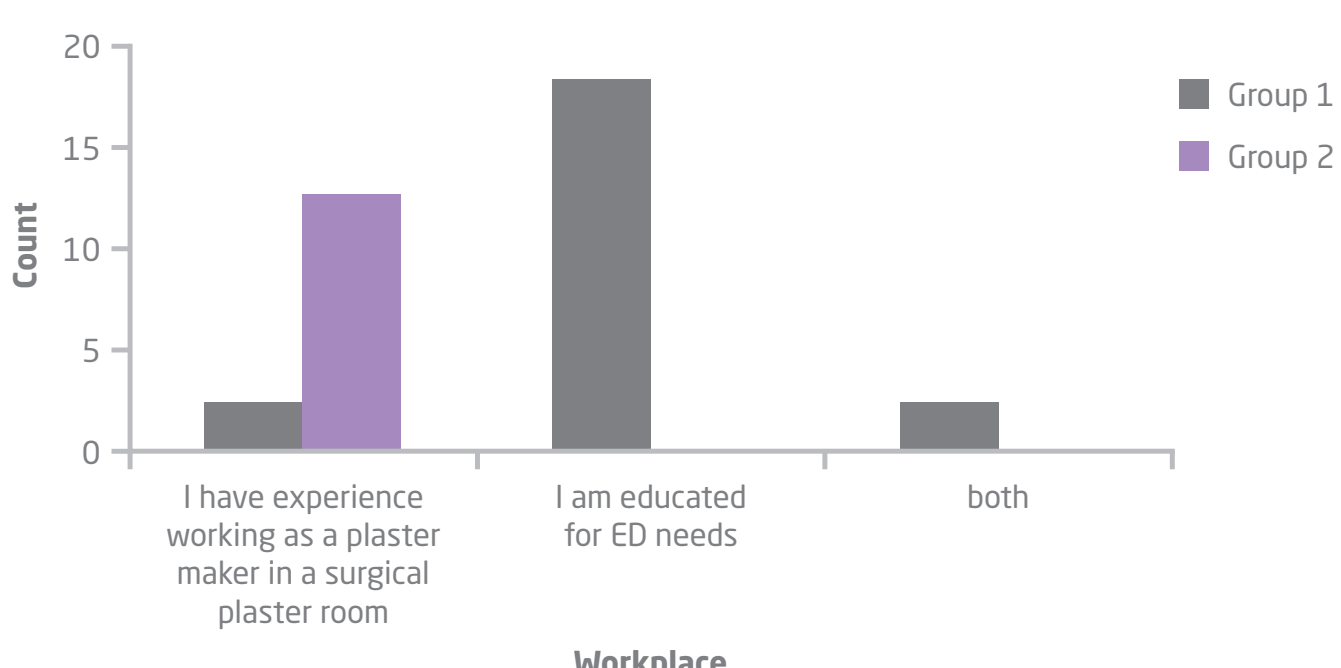

Figure 5. Overview of responses with regard to previous experience

When asked "If you were offered additional training in administering plaster splints, would you participate in it?", 83.3\% respondents from the first group responded positively, while $68.2 \%$ respondents from the second group answered in the same way. (Fisher's exact test, $p=0.439$ ).

\section{Discussion}

Back in 1852, Matthysen, a Dutch military surgeon, discovered how to successfully maintain the retention of a bone fragment and protect relations between the bone fragments by dipping cloth strips into water to which he added plaster (1). Although it is hard to imagine that 1852 is connected with the

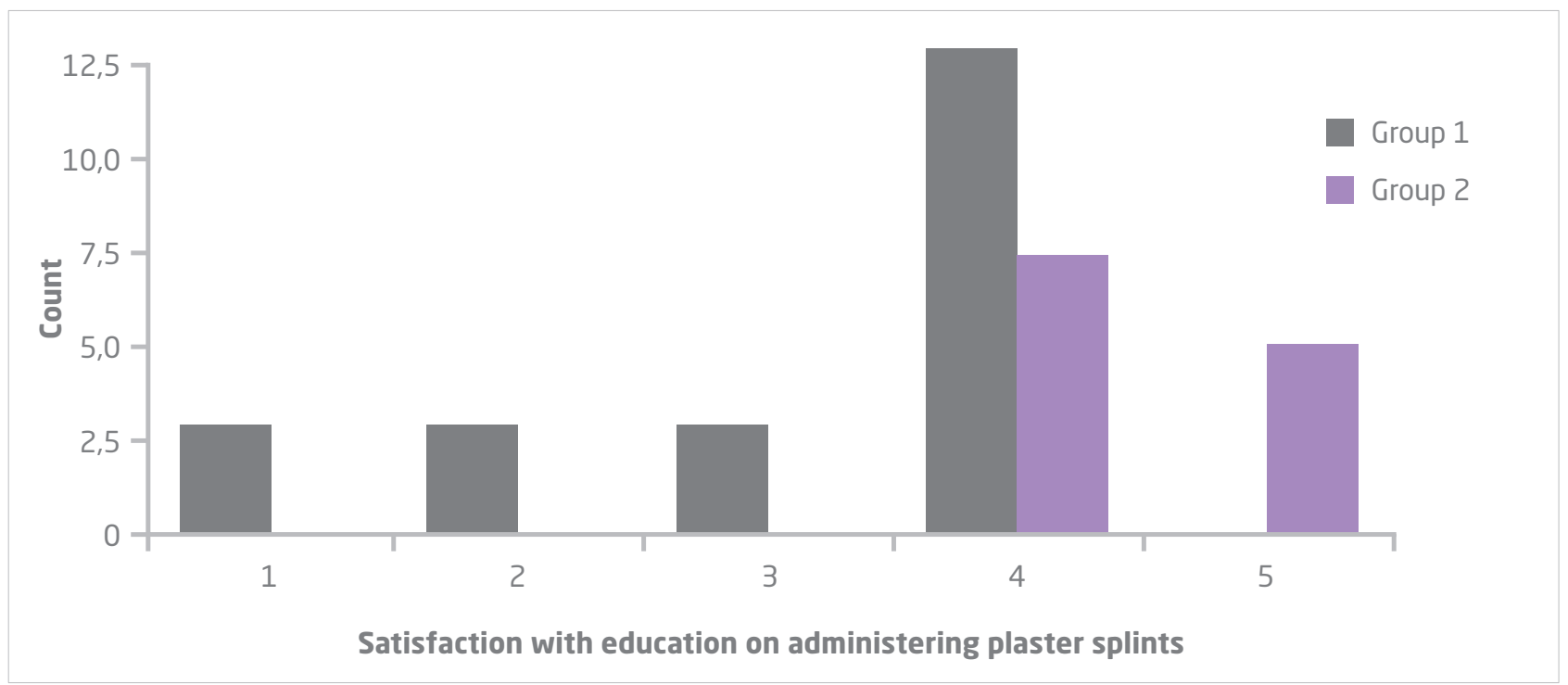

Figure 6. Overview of answers to the question "Satisfaction with education on administering plaster splints" 


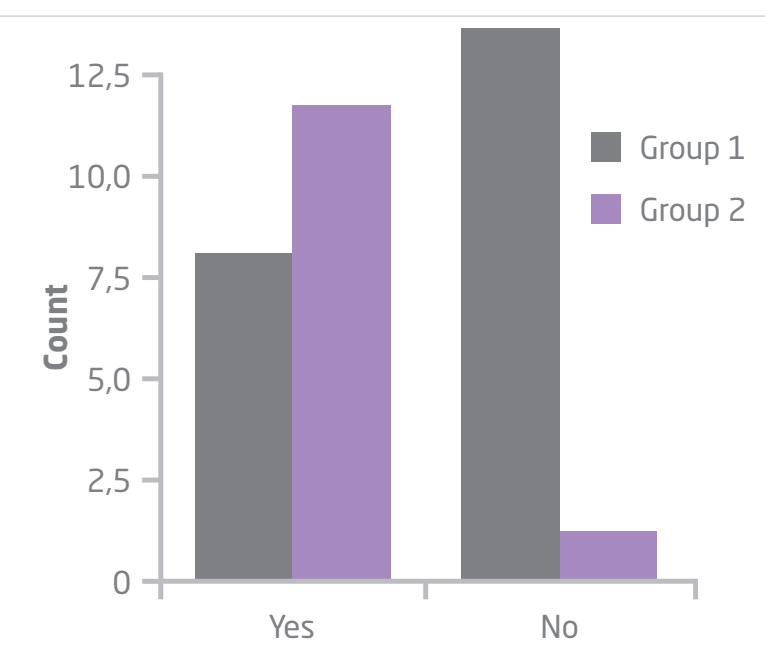

Do you think that education on administering plaster splints which you have received is sufficient?

Figure 7. Overview of answers to the question "Do you think that education on administering plaster splints which you have received is sufficient?"

conservative treatment of fractures in the $21^{\text {st }}$ century, the link exists. Despite the growing selection of different immobilization materials, plaster was used at the beginning of this century in $98 \%$ of performed immobilization cases, which makes it the most common $(1,4)$.

The study included 153 patients, who were divided into two groups. Respondents were treated with dorsal forearm and shin plaster splints because these are the two most common immobilization types (1, 5). There is no statistically significant difference regarding the representation of gender and age within the two groups. Women were represented in the first group by 29 respondents, and by 32 respondents in the second group, while there were 46 men in each group. Respondents from both groups were of equal age, the first group was 30.80 years old, and the second group was 35.86 years old. When assessing immobilization based on respondents' responses to the claim "Immobilization was comfortable", there is a statistically significant difference in the responses between the two groups $(p=0.000)$. Respondents from the first group agreed with this claim, as much as $98.7 \%$ of them, while the same was done by only $38.5 \%$ of respondents from the second group. When citing difficulties, respondents from the first group demonstrated better results than those from the

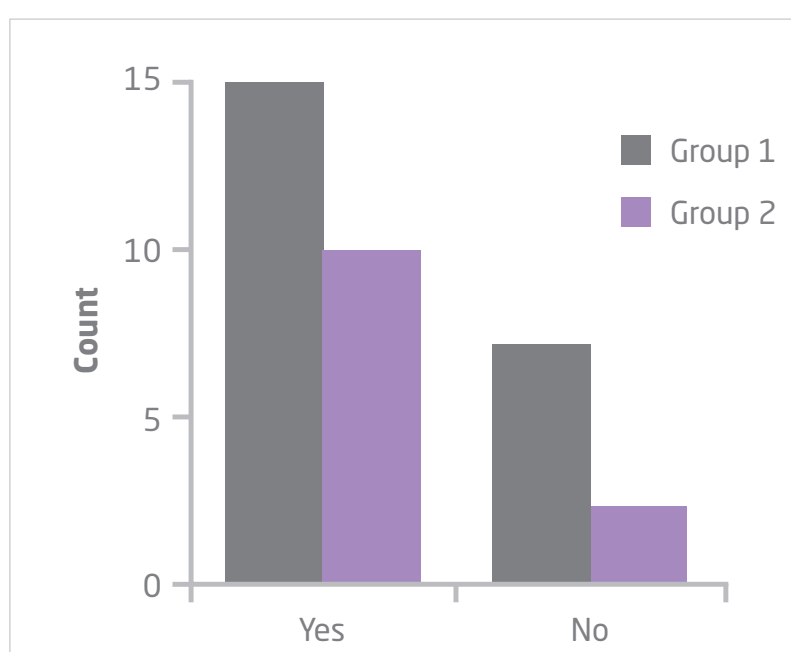

If you were offered additional training in administering plaster splints, would you participate in it?

Figure 8. Overview of answers to the question "If you were offered additional training in administering plaster splints, would you participate in it?"

second groups and mentioned fewer subjective difficulties. In the second group, respondents have more often reported "two or more difficulties" compared to the first group.

Respondents from the first group wore the immobilization device for 6.89 days on average, while the second group's average was 7.74 days. Here we see a statistically significant difference $(p=0.001)$, but we believe that this difference does not significantly affect any aspect of this research. When expressing pain intensity on a visually analogue scale (VAS), respondents assessed their pain with grade $2(6,7)$ on a scale of 0 to 10 , which constitutes light pain (6). Here no difference in expression of pain exists.

During the immobilization, $40 \%$ of respondents from the first group listed at least one subjective issue, while at the same time $65.4 \%$ of respondents from the second group did the same. Two or more subjective difficulties were reported more by respondents from the second group than from the first. That presents a statistically significant difference, amounting to $p=0.000$. Although these are subjective difficulties that depend on the person and their perception, some of them (e.g. swelling) are normal after an injury (post-traumatic oedema) (1). However, here we see an obvious difference in expressing difficulties between the groups. According to Hančević, "... the 
risk of post-traumatic oedema and circulatory disturbances should be explained and patients should be warned ..." and "well immobilized limb does not hurt, thus each patient with such difficulties should be examined carefully"; thus we can say that, between the two groups, there is a difference in the correctly set immobilization (1). An immobilization device which is too tight due to tight bandages, an insufficiently padded immobilization device, an immobilization device of inadequate width-length and/or inadequate education of patients during immobilization treatment can cause such disturbances $(1,8,9,10)$, so that may be the cause of these differences between the groups.

Gender and age are demographic variables that affect the experience of pain. For the purposes of credibility of the data obtained from the questionnaire, it is important to have an equal number of women and men in both groups, which we have shown through results $(11,12)$. Age has no significant influence on the intensity of pain (13). In assessing the immobilization using the claim "Immobilization was comfortable" and the question where the respondents were asked to indicate the difficulties they had experienced, respondents from the first group showed positive results in relation to the second group and it can be said that the respondents were more satisfied, and immobilization was more comfortable and caused fewer subjective problems. These subjective difficulties are signs of skin integrity damage (14, 15). The creation of post-traumatic oedema begins immediately after the trauma and stops a few days later (1). Plaster immobilization devices are solid cylinders which do not spread, thus this new oedema cannot expand anywhere and may lead to limb strangulation (1).

In assessing the complications of immobilization by a professional associate, we made a remarkable, if somewhat disturbing discovery (if you take into account that the immobilization device was not worn for a long time - approximately 7 days) that $8.9 \%$ of respondents had damaged skin integrity - pressure ulcers of various stages up to the appearance of necrotic tissue. This is extremely alarming and worrying because the treatment time was short, and we can only imagine what would have happened if the period was longer. Since we have previously mentioned that post-traumatic oedema subsides after a few days, "an empty space" can be created between the immobilization device and limbs (1). Movement of the immobilization device after the formation of these empty spaces causes persistent irritation $(1,4)$ of already developed and possibly undetected decubitus and it only makes it worse.

In the evaluation of the technical characteristics of immobilization, there is a statistically significant difference ( $p=0.000)$, and thus $86.7 \%$ of immobilization devices in the first group were adequate, while the result from the second group was only $41 \%$, i.e. in the second group there were $59 \%$ of immobilization devices that were inadequate in one or more technical segments (inadequate length, volume, limb not placed in the correct position, etc.). Regarding individual inadequacies, most often mentioned inadequacy in the second group was "inadequate length of the immobilization device". What exactly that means for the respondents will be explained on the example of a forearm plaster splint. Forearm immobilization incudes the area of the dorsal side of the forearm from metacarpophalangeal joints to just below the elbow (1) so that, if it is too long, it automatically limits the movement of the metatarsophalangeal joint and / or elbow. This situation leads to a decrease in the finger activity, whose purpose is increasing the circulation (16), which reduces the circulation function, i.e. fulfilment of tissue needs (17). This consequently causes muscle atrophy of the immobilized limb $(4,17)$. Muscle inactivity leads to muscle atrophy.

The difference between the two groups in the number of individuals who administered immobilization is statistically significant $(p=0.002)$. Here the difference is also in the demographic characteristics of respondents: in the first group all respondents were male, while in the second group there was an equal number of both sexes. Respondents from the first group were younger on average, i.e. the average age of respondents in the first group was $31.5+/-9.276$ years and in the second group $44+/-10.508$ years. According to the level of education, the majority of respondents from the first group have completed a secondary education, while $25 \%$ of them have a higher level of education. The second group had a higher percentage of respondents with a higher education degree. According to the source of knowledge about the plaster splints between the two groups, there is a statistically significant difference $(p=0.000)$. Respondents from the first group state that their knowledge is the result "of working as a plaster maker at the surgical clinic". On the other hand, respondents from the second group claim, as 
much as $81.8 \%$ of them, that their knowledge is the result of "education for working at EDs". The respondents from the first group, $58.3 \%$ of them, rated their satisfaction with education as good, while a very good grade was given by $41.7 \%$ of them. In the second group, $59.1 \%$ of respondents assessed their education as good or very good. Here we see a statistically significant $(p=0.005)$ difference between the two groups - respondents from the first group were satisfied with their training compared to those from the second group. Since we have previously shown that the training of the two groups differs, we can say that education on plaster immobilization which is the result of working at surgical clinics as a plaster maker gives greater satisfaction than in the second group that was trained only for purposes of working at EDs. When these results are linked with the previous result, it can be concluded that staff trained on immobilization at EDs is not sufficiently trained or is less trained compared to those who have worked in a surgical plaster room. The justification for this claim can be found in the Ordinance on EDs Performance, by which a space for the installation and necessary accessories was ensured, but not for training for the workplace, as opposed to the workplace of triage nurses (18).

When asked "Do you think that education on administering plaster splints was sufficient?", respondents from the first group answered mostly positive $(91.7 \%)$, while the same answer was given by only $36.4 \%$ of respondents from the second group.

Respondents from the first group, as much as $83.3 \%$ of them, stated that they were willing to undergo further education on administering immobilization, whereas in the second group the same statement was made by $68.2 \%$ of respondents. Respondents from the first group still gave positive answers related to their education, so we have far more positive results in the first group compared to the second group regarding the belief that the education they had received was sufficient. However, a high percentage of them is ready to undergo additional education, if possible. We must admit that despite a lower level of education of the respondents in the first group, in each segment of the tests they showed better results compared to the second group. This is somewhat non-specific when looking at the general population characteristics. Respondents from the second group should have achieved better results because of their higher academic level. We believe this case is reversed because immobilization, i.e. knowledge on immobilization, is a highly specialized area that covers only a segment of trauma patients' health care and requires specific knowledge and skills. Even though respondents from the first group had better results and stated that they "have experience of working at a surgical clinic as plaster makers", we did not find any written record, or any professional literature in Croatian aimed at the development of immobilization which was written for nurses who administer immobilization. Standardized training in the Croatian health care system for making immobilization devices does not exist. According to our empirical experiences, there are only individual efforts; training that is passed on "from generation to generation" which we consider insufficient. According to the Nursing Act in force, Article 5: "Health/nursing care involves the application of specific knowledge and skills based on scientific knowledge from nursing, natural, medical and human sciences" and Article 10: "Further training of nurses is conducted when the scope and complexity of activities and expected results require additional training or specialization in a particular area of health care" (19), while the competence issued by the Croatian Chamber of Nurses reads: "immobilises damaged limb - using plaster bandage, a metal splint, vacuum splints" (20). We believe it is necessary (as stated in the above Arti(les), to provide additional training which would lead to reducing and equalizing the frequency of complications of immobilization treatments, improving the quality of life of patients treated with immobilization and technically correct immobilization that is made according to the rules of our profession. The British Orthopaedic Association standards on administering plasters state: "Standards need to be formulated to promote the likelihood of the service being delivered safely and effectively, to be clear about what has to be done to comply, to be informed by an evidence base and to be effectively measurable" (21). Among other things, we must strive for standardization and written instructions as is the case in other countries in Europe $(21,22)$. Sharma et.al. in their work claimed "Most complications can be avoided by using proper immobilization techniques" (10). 


\section{Conclusion}

Based on this study, the following can be concluded: there is a statistically significant difference in responses between the two groups of respondents who participated in the study. The respondents from the second group who were treated with plaster immobilization, which was administered by nurses who were trained in administering immobilization for the purposes of working at EDs, more frequently listed subjective difficulties (pinching, itching, swelling) and were much more likely to give a negative grade for immobilization comfort than respondents from the first group. Respondents from the second group were more likely to suffer pressure ulcers during the immobilization than respondents from the first group. Immobilization devices in the first group were technically adequate in $86.7 \%$ of cases and in the second group the same can be said for $41 \%$ of respondents.

Male nurses in the first group were much more likely to express a positive result of training they received in administering immobilization and considered that it was sufficient compared to nurses in the second group. Between the two groups, there is a difference in every estimated segment. Respondents from the second group on average recorded more negative results compared to the first group, and based on these results, the importance of further education should be noted. Standardized training for nurses - plaster makers does not exist in the health system of the Republic of Croatia. This could be an area for greatest improvement. In the future, it will be necessary to determine the level and type of education at EDs and how to provide all health care system users with the same quality of services.

The hypothesis is confirmed.

\section{Acknowledgements}

I wish to thank my colleagues who collected data at institutions that were a part of this research: Zdravko Mikolaj, Ivan Hulak, Dubravka Kuzmić and Danijel Barbarić.

\section{References}

1. Hančević J, Antoljak T, Korać Ž. Imobilizacija. Zagreb: Medicinska naklada; 2001. Croatian.

2. Petersen W, Rembitzki IV, Koppenburg AG, et al. Treatment of acute ankle ligament injuries: a systematic review. Arch Orthop Trauma Surg. 2013;133(8):11291141. doi:10.1007/s00402-013-1742-5.

3. Van den Bekerom MP, Struijs PA, Blankevoort L, Welling L, van Dijk CN, Kerkhoffs GMM. What Is the Evidence for Rest, Ice, Compression, and Elevation Therapy in the Treatment of Ankle Sprains in Adults? J Athl Train. 2012;47(4):435-443.

4. Gašić M. Kvaliteta života kod konzervativnog liječenja prijeloma distalnog dijela podlaktice imobilizacijskim materijalima [final paper]. Varaždin: Sveučilište Sjever 2015. Croatian. Available from: https://urn.nsk.hr/ urn:nbn:hr:122:245262

5. Mahaffey D, Hilts M, Fields KB. Ankle and foot injuries in sports. Clin Fam Pract: 1999; 1(1):233-50.

6. Slavetić $G$, Važanić D. Trijaža u odjelu hitne medicine. Zagreb: Ministarstvo zdravlja, Hrvatski zavod za hitnu medicine; 2012. Croatian.

7. Hawker GA, Mian S, Kendzerska T, French, M. Measures of adult pain: Visual Analog Scale for Pain (VAS Pain), Numeric Rating Scale for Pain (NRS Pain), McGill Pain Questionnaire (MPQ), Short-Form McGill Pain Questionnaire (SF-MPQ), Chronic Pain Grade Scale (CPGS), Short Form-36 Bodily Pain Scale (SF-36 BPS), and Measure of Intermittent and Constant Osteoarthritis Pain (ICOAP). Arthritis Care Res (Hoboken). 2011;63 Suppl 11:S240-52. doi: 10.1002/acr.20543.

8. Harter R, Jagdeld A, Kern G, Martini G, Neumann K. Checklisten der aktuellen Medizin, Checkliste Gipstechnik, Fixationsverbände. Thieme; 1998.

9. Vranić J, Anušić M. Gipsane i ekstenzione imobilizacije. Sarajevo: Svjetlost; 1985.

10. Sharma H, Prabu D. Plaster of Paris: Past, present and future. J Clin Orthop Trauma. 2013;4(3):107-9. doi: 10.1016/j.jcot.2013.09.004.

11. Modić Stanke K, Ivanec D. Ovisnost doživljaja boli o socijalnom kontekstu. Suvremena psihologija. 2008; 11(1): 25-38. Croatian. Avliable from: http://hrcak.srce.hr/81396

12. Unruh, AM. Gender variations in clinical pain experience. Pain. 1996; 65: 123-167.

13. Havelka M. O boli. In Havelka M. (editor). Zdravstvena psihologija. Jastrebarsko: Naklada Slap; 2002. p 159208. Croatian.

14. Hančević J. Dekubitus. Zagreb: Medicinska naklada; 2003. Croatian.

15. Prpić I et al. Kirurgija za medicinare. Zagreb: Školska knjiga; 2005. Croatian 
16. Smiljanić B. Traumatologija. Zagreb: Školska knjiga; 2003. Croatian

17. Guyton AC, Hall JE. Medicinska fiziologija. Zagreb: Medicinska naklada; 2003. Croatian

18. Narodne novine. Pravilnik o minimalnim uvjetima u pogledu prostora, radnika i medicinsko-tehničke opreme za obavljanje djelatnosti hitne medicine. 2016: br.71. Croatian. Available from: http://narodne-novine.nn.hr/clanci/ sluzbeni/2011_04_42_994.html. retrived 03.08.2016.

19. Narodne novine. Zakon o sestrinstvu. 2003: br.121. Available from: http://narodne-novine.nn.hr/clanci/ sluzbeni/2003_07_121_1710.html Croatian.

20. Šepec S. Kompetencije medicinskih sestara opće zdravstvene njege. Zagreb: HKMS; 2011. Croatian.

21. British Orthopaedic Association. Castings standards. London; 2015. Available from: https://www.boa. ac.uk/wp-content/uploads/2015/12/BOA-NationalCasting-Standards.pdf

22. Barrett D, Howard R. Guidelines on the Application of Plaster of Paris "Backslab" Casts in the Emergency Department. Nursing Practice Committee: 2012. Available from: http://www.olchc.ie/Files-Uploaded/ Nursing-Guidelines/Plaster-of-Paris-Backslab-castsin-the-ED-2012.pdf 


\section{UČESTALOST KOMPLIKACIJA U BOLESNIKA LIJEČENIH SADRENOM UDLAGOM U OBJEDINJENIM HITNIM BOLNIČKIM PRIJEMIMA ČETIRIJU BOLNICA}

\section{Sažetak}

Ciljevi. 1. Utvrditi učestalost komplikacija u bolesnika liječenih sadrenom udlagom u OHBP-ima.

2. Utvrditi postojanje povezanosti komplikacija u bolesnika liječenih sadrenom udlagom u OHBP-ima s iskustvom prijašnjeg rada u kirurškim gipsaonicama.

Hipoteza. Učestalost komplikacija kod bolesnika liječenih sadrenom udlagom u OHBP-ima kojima su imobilizaciju postavljali medicinske sestre ili medicinski tehničari s prijašnjim iskustvom rada u kirurškim gipsaonicama manja je nego u bolesnika kojima su imobilizacije postavljali medicinske sestre ili medicinski tehničari educirani za potrebe gipsanja u OHBP-ima.

Materijali i metode. Istraživanje: travanj i svibanj 2015. godine u OB-u Našice, KBC-u Osijek, ŽB-u Čakovec i OB-u Dr. Tomislav Bardek Koprivnica. Uzorak: 153 bolesnika i 34 medicinske sestre / medicinska tehničara. Instrumenti istraživanja: dva anonimna anketna upitnika kreirana za potrebe istraživanja. Primijenjena je deskriptivna i neparametrijska statistička obrada, razina značajnosti postavljena je na $\alpha=0,05$.

Rezultati. Dekubitus različitog stupnja javlja se kod $8,9 \%$ ispitanika druge skupine, u prvoj skupini ta komplikacija nije zabilježena. Sadrene su udlage u prvoj skupini adekvatne u 86,7 \% slučajeva, a u drugoj su skupini neadekvatne u $59 \%$ slučajeva.

Zaključak. Hipoteza je potvrđena.
Ključne riječi: OHBP, sadrena udlaga, imobilizacija, edukacija, komplikacije 